\title{
The Individual Inventor Motif in the Age of the Patent TROLL
}

\author{
Christopher A. Cotropia ${ }^{*}$
}

12 YALE J.L. \& TECH. 52 (2009)

\begin{abstract}
The individual inventor motif has been part of American patent law since its inception. The question is whether the recent patent troll hunt has damaged the individual inventor's image and, in turn, caused Congress, the United States Patent and Trademark Office (USPTO), and the courts to become less concerned with patent law's impact on the small inventor. This Article explores whether there has been a change in attitude by looking at various sources from legislative, administrative, and judicial actors in the patent system, such as congressional statements and testimony in discussions of the recent proposed patent reform legislation, the USPTO's two recently proposed sets of patent rules and responses to comments on those rules, and recent Supreme Court patent decisions. These sources indicate that the rhetoric of the motif has remained unchanged, but its substantive impact is essentially nil. The motif has done little to stave off the increasingly antiindividual-inventor changes in substantive patent law. This investigation also provides a broader insight into the various governmental institutions' roles in patent law by illustrating how different institutions have responded-or not responded-to the use of the individual inventor motif in legal and policy arguments.
\end{abstract}

\footnotetext{
* Professor of Law, Intellectual Property Institute, University of Richmond Law School. Thanks to Kevin Collins, Jim Gibson, Jack Preis, Arti Rai, Josh Sarnoff, and the participants at the Patents and Entrepreneurship in Business and Information Technologies symposium hosted at George Washington University Law School for their comments and suggestions on an earlier draft. Special thanks to the Ewing Marion Kauffman Foundation, the Microsoft Corporation, and the George Washington University Law School Intellectual Property Center for the research grant that supported the writing of this Article.
} 


\section{TABLe OF CONTENTS}

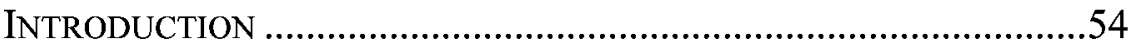

I. The Individual InVENToR and the United STATES PATENT SYSTEM …………………………………….......57

A. The Individual Inventor Motif Defined ..............................57

B. Historic Usage of the Motif .............................................. 58

1. Legislative .................................................................59

2. Administrative .............................................................60

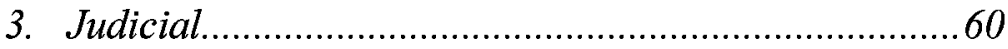

II. "Patent Trolls" and the Individual InVentor Motif .....61

A. Patent Trolls and the Current Patent Reform Movement. 61

1. The Patent Troll........................................................62

2. Definitional Problems ...............................................63

B. The Patent Troll's Impact on the Individual Inventor Motif 64

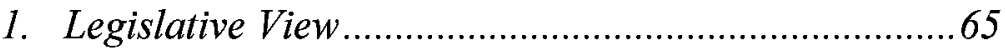

2. Administrative View..................................................69

3. Judicial View.......................................................... 73

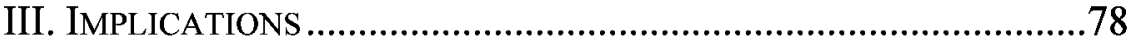

A. Resilience of the Motif's Rhetoric.................................... 79

B. Lack of Substance Behind the Motif ................................. 79

C. Roles of the Different Institutions in Patent Law.............. 81

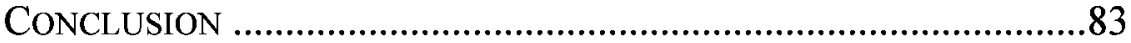




\section{INTRODUCTION}

The garage inventor is as American as apple pie. ${ }^{1}$ We enjoy stories of independent inventors, working against all odds to provide society with amazing technological breakthroughs. The stories are so entertaining that popular movies are made about such individuals - such as Flash of Genius, telling the story of Robert Kerns, the inventor of the intermittent windshield wiper system. ${ }^{2}$ Intel has even launched an ad campaign championing the individual inventor, portraying individuals such as Alay Bhatt, the inventor of the Universal Serial Bus (USB), as modern-day rock stars. $^{3}$

The individual inventor story generally goes as follows: A lone individual toils in her limited free time-evenings after work and perhaps the weekend - to come up with an amazing breakthrough that turns out to be incredibly beneficial to society. This entrepreneur is unconstrained by both the bureaucracy of a large corporate structure and the traditional thinking in a given

1 See Mark D. Janis, Patent Abolitionism, 17 BERKELEY TECH. L.J. 899, 910 (2002); Michael J. Meurer, Inventors, Entrepreneurs, and Intellectual Property Law, 45 Hous. L. REV. 1201, 1202-03 (2008).

An important point of clarification needs to made up front concerning this Article's use of the term "individual inventor." While this term clearly includes individuals, who by themselves invent, the term has also been used in the literature to include small businesses and entrepreneurs. See Meurer, supra note 1 , at 1201-04 (using the terms such as "small innovative firms," "small business," "small entities," "entrepreneurs," and "inventors" interchangeably when discussing how patent law handles this class of inventors); Janis, supra note 1 , at 920 (discussing both "independent inventors" and "small business" when exploring the "heroic inventor motif"). Even the United States Patent and Trademark Office lumps these individuals together when defining "small entity." See 37 C.F.R. \& 1.27 (2009) (including a "person, small business concern, or nonprofit organization" in the definition).

This Article will follow the same custom and include all of these inventors when using the term "individual inventors." However, these classes of inventors have their differences, and these differences could come out in both the usage of distinct motifs (individual inventor versus small business inventor motif) and substantive impact. Such fidelity is not explored in this Article, mainly because, like those commentators and the USPTO before, these different inventors are usually lumped together, both in rhetoric and substantive analysis. I thank the editors at the Yale Journal of Law and Technology, particularly Molly Boyle, for raising this point.

2 See Flash OF Genius (Univ. Pictures et al. 2008).

3 See Intel Corp., An "Intel Start" TV Ad-Sponsors of Tomorrow, http://www.youtube.com/watch?v=jqLPHrCQr2I (last visited Nov. 11, 2009).

4 See Meurer, supra note 1, at 1202-03 ("Received wisdom holds that small business plays an especially important role in the American economy in terms of job creation, and that entrepreneurs are disproportionately responsible for revolutionary innovations."). 
technological field. The drive and ingenuity of these small inventors is the life-blood of American innovation. It's hardworking, creative individuals like Thomas Edison, Steve Jobs, and Bill Gates that bring about true innovations.

This "individual inventor motif" - that small inventors play a crucial role in creating revolutionary inventions and, in turn, spurring the American economy-is, for the most part, widely accepted. ${ }^{5}$ The individual inventor motif is perhaps strongest in those technologies where independent invention is most likelysuch as the information technologies and business methods. These are technological areas where resources do not act as a high barrier to invention, and thus small inventors can easily participate. ${ }^{6}$ The patent system has traditionally taken the individual inventor motif to heart and seen patents as a vehicle to both fuel individual inventors and protect them from large corporations. ${ }^{7}$

There is another, newer narrative that Americans are becoming more and more aware of - the story of the "patent troll., $"$ The narrative is as follows: patent trolls are patent holders who, while not commercializing the patented invention themselves, seek royalties from other companies who have. ${ }^{9}$ They hold up such companies, asserting their patent rights at the right time to maximize the royalties they can get. For patent trolls, patenting is about profit, not invention.

If a defendant is sued by one of these patent trolls, the alleged infringers do not have the usual retaliatory mechanismthe ability to assert their own patents in return-because the patent troll does not sell any products or offer any services which could infringe. The lack of production by the patent troll also means that society receives no benefit from the patent, just the tax of the patent troll. ${ }^{10}$ Such "trolling" is common in the same fields that

5 Id.; see also Janis, supra note 1, at 910-11.

6 See John R. Allison, et al., Software Patents, Incumbents, and Entry, 85 TEX. L. REV. 1579, 1580-81 (2007).

7 See, e.g., J. Douglas Hawkins, Importance and Access of International Patent Protection for the Independent Inventor, 3 U. BALT. INTELL. PROP. L.J. 145,148 (1995) ("Independent inventors accounted for about half of all patent filings in the United States around fifty years ago.").

8 See, e.g., Laurie J. Flynn, Chip Maker Wins Battle, but Faces Bigger War, N.Y. TIMES, Sept. 29, 2008, at C8 ("Patent troll is a derogatory term used to describe companies or individuals who make their money suing companies for patent infringement.").

9 John M. Golden, Commentary, "Patent Trolls" and Patent Remedies, 85 TEX. L. REV. 2111, 2112 (2007).

10 See Mark A. Lemley \& Doug Lichtman, Rethinking Patent Law's Presumption of Validity, 60 STAN. L. REV. 45, 48 (2007) ("Sadly, a large and growing number of 'patent trolls' today play this exact strategy, using patents on obvious inventions quite literally to tax legitimate business activity."); Daniel J. McFeely, An Argument for Restricting the Patent Rights of Those Who Misuse 
most individual inventors operate in -information technologies and business methods. These technological areas are more susceptible to hold-up because many of the products are multicomponent, allowing a patent covering even the smallest part to hold-up the whole technology. ${ }^{11}$ When the product is particularly valuable, even a patent on a small component can facilitate the extraction of a large rent.

The intersection of these two popular narratives - that of the individual inventor and that of the patent troll-is the focus of this Article. Patent trolls are the targets of the current patent reform movement. ${ }^{12}$ One of the difficulties that has plagued the push for change, however, is a definitional one-what exactly is a patent troll? ${ }^{13}$

This is where the individual inventor-the person who is supposed to be promoted by the patent system - comes in. The individual inventor could easily fit within some definitions of a patent troll- both are individuals who are non-producing and monetize their patents by seeking royalty arrangements with larger companies. The biggest difference is that traditional thinking vilifies one and reveres the other.

This Article examines this intersection to gain a better understanding of the place of the individual inventor motif in patent law. The individual inventor has been championed even before there was United States patent law. But how has the hunt for the patent troll impacted the individual inventor motif? This Article answers that question by looking at both the rhetorical use of the motif and the impact of substantive changes on individual inventors in all three branches of government-Congress, the United States Patent and Trademark Office (USPTO), and the courts (particularly the Supreme Court). ${ }^{14}$ What this Article finds is that the individual inventor motif is incredibly resilient, at least rhetorically, remaining essentially unscathed by the introduction of

the U.S. Patent System To Earn Money Through Litigation, 40 ARIz. ST. L.J. 289, 290-91 (2008) (discussing how the patent troll "causes harm to society").

11 Mark A. Lemley \& Carl Shapiro, Patent Hold-up and Royalty Stacking, 85 TEX. L. REV. 1991, 2008-09 (2007).

12 See Paul J. Heald, Optimal Remedies for Patent Infringement: A Transactional Model, 45 Hous. L. REV. 1165, 1199 (2008) ("To conclude, one thrust of current patent reform efforts focuses on remedies, with the most frequent object of discussion being the 'patent troll,' the nonexploiting owner of a patent whose business model is based on extracting licensing fees from unintentional infringers.").

13 Ronald J. Mann, Do Patents Facilitate Financing in the Software Industry?, 83 TEX. L. REV. 961, 1023-24 ("[It] is difficult to discern any principled distinction between the desire of the inventor to appropriate the value of his invention and the desire of operating firms to appropriate the value of their inventions.").

14 See infra Section II.B. 
the patent troll into the discourse. ${ }^{15}$ This inquiry also unveils additional, beneficial information about the motif. For example, the motif's positive rhetoric is completely divorced from the mostly negative substantive impacts of patent law changes on individual inventors. While the rhetoric lives on, almost every recent patent law change has been to the detriment of small inventors. ${ }^{16}$ Variations in the motif's usage also tell a great deal about the various governmental institutions' roles in the patent system - with the USPTO catering the most to individual inventors and the courts being the most insulated from and apathetic toward such interests. ${ }^{17}$

This Article proceeds in three Parts. Part I describes the individual inventor motif and looks at the use and treatment of the motif in the patent system prior to the advent of the patent troll. Part II then examines the impact of the introduction of the patent troll, both on the motif's rhetorical usage and the substantive impact of patent law changes on the individual inventor. Finally, Part III explores the implications of the Article's findings, both for the motif itself and for understanding the roles of various institutions in the patent system. Furthermore, pushes for patent reform at all three institutions have been constant over the past several years. Those who engage the patent system for reform can also learn about the motif's effectiveness from this Article's findings. ${ }^{18}$ The additional insight into how the different institutions operate within the patent system can help such activists further, shedding light on which arguments play better in different venues.

\section{The Individual InVentor AND the United STATES Patent System}

\section{A. The Individual Inventor Motif Defined}

Americans see the individual inventor as crucial to the production of new inventions and innovations. This view of the individual inventor, what I call "the individual inventor motif," is infused throughout much of the history of the United States patent system. ${ }^{19}$ The motif's use supports the conclusion that one of the

5 See infra Section III.A.

16 See infra Section III.B.

17 See infra Section III.C.

18 See, e.g., Amy Kapczynski, The Access to Knowledge Mobilization and the New Politics of Intellectual Property, 117 YALE L.J. 804, 838 (2008) ("The process that has led to this reform effort has also turned up significant rifts in the coalition of IP industries.").

19 The motif's origins trace back well before the U.S. patent system. Janis, supra note 1, at 908-10 (discussing the British patent system's invocation of the individual inventor motif). 
main goals of the patent system should be to assist, and in some ways protect, the individual inventor. ${ }^{20}$

The patent laws do very little to prompt this view. ${ }^{21}$ The U.S. Constitution does identify "Inventors"- the individual creator, not corporations - as the target of the patent incentive. ${ }^{22}$ And many of the founding fathers, the same individuals who played a significant role in shaping the U.S. patent system, were solo inventors themselves. ${ }^{23}$ Rather than resulting from any legislation, statute, or even the Constitution, invocations of the individual inventor motif in patent discourse are the product of the collective belief in the narrative itself: that small inventors are crucial to technological innovation and that the patent system should support their activities.

\section{B. Historic Usage of the Motif}

All three governmental branches have employed the individual inventor motif before and have often made it part of their analysis of the patent system. Mark Janis noted in his discussion of what he calls the "heroic inventor motif" "[c]ommentaries and legislative studies on U.S. patent law reform in the mid-twentieth century periodically acknowledged the interests of independent inventors." ${ }^{25}$ The USPTO has also played to the motif, mainly through its separate fee structure and tailored resources for individual inventors. ${ }^{26}$ The courts, though not as

20 Id. at 910-12. Meurer points out that it is far from clear that patents actually help individual inventors, particularly the slightly larger small company obtaining patents. Meurer, supra note 1, at 1230-35.

21 Meurer, supra note 1, at 1203-04 ("Only a few IP law doctrines target small firms for specific benefits ....").

${ }^{22}$ U.S. CONST. art. I, $\S 8$ ("To promote the Progress of Science and useful Arts, by securing for limited Times to Authors and Inventors the exclusive Right to their respective Writings and Discoveries ...."). The patent statutes also award patents to named inventors, not corporations. 35 U.S.C. $\S 116$ (2006).

${ }_{23}$ See Dana Rohrabacher \& Paul Crilly, The Case for a Strong Patent System, 8 HARV. J.L. \& TECH. 263, 270 (1995) (noting many of nation's founding fathers were technologists).

24 While Janis uses the term "heroic inventor motif" versus this Article's usage of "individual inventor motif," there is not much substantive difference between what the articles are discussing. Janis focuses more on what the individual inventor does-create a major invention-while I am focusing on a larger class of individuals-all individual inventors, regardless of the significance of their discovery.

${ }_{25}$ Janis, supra note 1, at 916.

26 Janis also notes that "[a]nother example comes from mid-1960's symposium commentary from PTO officials in honor of the $175^{\text {th }}$ anniversary of the U.S. Patent System. A symposium article published in the Journal of the Patent Office Society offered a poetic ode to the 'Godly Inventor,' commencing, 'A spark ignites your restless mind, a fearless soul, it starts to grind." Id. at 912 
much as the legislative and administrative actors, have also given credence to the individual inventor narrative. ${ }^{27}$

Janis cataloged usage of the individual inventor motif in patent law in the late 1990s and early 2000s. All three branches paid homage to the individual inventor, albeit in varying degrees.

\section{Legislative}

In Congress, the main reform effort during the period Janis studied was the legislation that eventually passed as the American Inventor's Protection Act of $1999 .{ }^{28}$ Key provisions in the bill dealt with the publication of the patent application prior to issuance. ${ }^{29}$ The proposed legislation changed the longstanding practice that kept applications secret until the patent was allowed and issued. The legislation as originally proposed would publish all applications eighteen months after filing. ${ }^{30}$

Janis noted that this publication requirement met strong resistance from the individual inventors' lobby, which argued that early publication would essentially lead to theft of the small inventor's ideas by large corporations. ${ }^{31}$ As William P. Parker, President of the Vermont Inventors Association, put it, "[t]he ideathieves can make money from the idea before the patent even issues and when they are challenged, are in a better position financially to defend themselves than the legitimate owner."32

Congress responded by amending the proposed legislation to allow patent applicants to opt out of the eighteen-month publication if the applicant was willing not to file for patents in foreign jurisdictions (which required such pre-publication). ${ }^{33}$ This amendment allowed individual inventors, who most likely would not be filing foreign given the high cost and low benefit of such filing to individuals, to avoid the danger of theft from early publication. Congress also changed the name of the legislation to the American Inventor's Protection Act, explicitly paying homage to the individual inventor. ${ }^{34}$ The legislation also included provisions to help protect small inventors from the invention

(quoting Isaac Fleischmann, The Patent Office and the Independent Inventor, 47 J. PAT. OFF. SOC'Y 459, 465 (2965)).

${ }^{27}$ Id. ("The heroic inventor motif also manifests itself in judicial opinions.").

28 Id. at 919-20.

29 Id.

$30 \quad I d$.

31 Id.

32 Id. (quoting The Omnibus Patent Act of 1997: Hearings on S. 507 and H.R. 400 Before the S. Comm. on the Judiciary, 105th Cong. 49 (1997)).

3335 U.S.C. $\S \S 122(b), 154(b)$ (2006).

34 Janis, supra note 1, at 920. 
promotion business. ${ }^{35}$ The final legislation did, however, contain provisions that individual inventors opposed. ${ }^{36}$ But the changes made and the final naming of the act evidenced Congress's willingness to assist the individual inventor.

\section{Administrative}

The motif was also alive and well at the USPTO in the late 1990 s and early 2000s. The USPTO's website contained a special set of resources for small inventors. As Janis noted, the USPTO's "Independent Inventor Resources"37 section started with the following text: "To paraphrase our Declaration of Independence, America is the land of the free, home of the brave, and haven for the independent inventor. Nowhere else in the world does a government exist that supports its independent inventors to the extent that we do. The independent inventor is America's natural resource." 38 As it has historically, the PTO also maintained a separate fee schedule for small inventors, allowing those who qualified for small entity status to pay essentially half the usual amount for most patent application filing fees. ${ }^{39}$

\section{Judicial}

Some judges, while not as much as Congress and the USPTO, have also shown some concern for individual inventors during the time period studied by Janis. For example, Judge Linn of the United States Court of Appeals for the Federal Circuit dissented from the court's en banc ruling on prosecution history estoppel, arguing, in part, that the majority's rigid rule "wrongfully set[] in place a regime that increases the cost and complexity of patent prosecution to the detriment of individual inventors" 40 and "discount[ed] the intrinsic worth in treating more fairly the individual inventor whose patent right is under administrative

3535 U.S.C. § 297; Janis, supra note 1, at 921.

36 Janis, supra note 1, at 919-21; Phyllis Schlafly, Don't Fall for "Phony Patent Reform," INVENTORS VOICE, Aug. 1, 1999, http://www.inventionconvention.com /inventorsvoice/urgentalerts/080199schlafly.html ("This bill is called the American Inventors Protection Act, but should be called the Inventors Elimination Act. The independent inventors would be squeezed out and their inventions stolen from them, all for the benefit of the foreigners and the giant corporations.").

37 Janis, supra note 1, at 911.

38 Id. (quoting Independent Inventor Resources, http://www.uspto.gov/web/

offices/com/iip/welcome.htm (last visited Dec. 20, 2001)).

39 Muerer, supra note 1, at 1203-04.

40 Festo Corp. v. Shoketsu Kinzoku Kogyo Kabushiki Co., 234 F.3d 558, 620

(Fed. Cir. 2000) (en banc) (Linn, J., concurring in part and dissenting in part). 
scrutiny." ${ }^{41}$ Janis also identified other times Federal Circuit judges, during this time period, discussed a particular patent rule's impact on small inventors. ${ }^{42}$ Notably, however, the individual inventor motif never really played a deciding role in a majority decision during the time period Janis studied. While individual judges have discussed individual inventors, the courts, in majority opinions, have not.

\section{II. “Patent Trolls" and the Individual Inventor MoTIF}

Given the persistence of the motif's presence in patent law, Janis's conclusion in 2002 that "[o]ne cannot help but expect that patent law reform debates will continue to revert periodically to narratives about the heroic inventor" seemed, at the time, incontrovertible. ${ }^{43}$ However, recently a new "favorite villain" of the patent system has arrived - the " "patent troll" . . one of a class of patent owners who do not provide end products or services themselves, but who do demand royalties as a price for authorizing the work of others." ${ }^{44}$ This description arguably includes the individual inventor, perhaps jeopardizing the individual inventor's role in patent reform debate. The question, explored below, is whether the advent of the patent troll has affected the individual inventor motif in the patent system-both the rhetorical use of the motif and the substantive impact on individual inventors.

\section{A. Patent Trolls and the Current Patent Reform Movement}

A major concern of current patent reformists is patent holdup. ${ }^{45}$ A patentee has a patent on a given product, or more likely a single component of a given product, and uses that patent to hold up the product and its producer after the producer has made a significant investment getting the product to market. ${ }^{46}$ This holdup situation is particularly problematic when the patent holder is a non-producer. ${ }^{47}$ That is, the patentee does not manufacture the patented invention herself. This exacerbates the situation because society does not gain anything from the patentee herself because the product does not go to market, and the alleged infringer has

$41 \quad I d$. at 628.

42 See Janis, supra note 1, at 913-14 (citing examples in the on-sale bar, public use bars, and remedies areas).

${ }^{43} I d$. at 922.

44 Golden, supra note 9, at 2112.

45 Lemley \& Shapiro, supra note 11, at 2008-09.

46 Id.

47 Id. 
little recourse, because the common counterstrategy of threatening the patentholder with patent infringement is often useless. ${ }^{48}$

\section{The Patent Troll}

The patentees who are non-producing and engage in holdup behavior have been labeled "patent trolls." ${ }^{.49}$ Patent troll activity is generally frowned upon because they act as only "tollkeepers" on the road of innovation. ${ }^{50}$ Patent trolls tax innovation by extracting licensing revenue without giving back anything in return. ${ }^{51}$ Instead, "[b]y acquiring [patent] claims and threatening or pursuing litigation, the patent trolls seek and often receive economic settlements from genuine innovators and producers that greatly exceed the true economic value of the patents in question." 52 The hold-up is "harmful rent-seeking," extracting more value then what the patent is worth. ${ }^{53}$

Modern patent reform efforts are directed towards solving the patent troll/hold-up problem. Two of the initial reports that sparked the modern patent reform movement - the Federal Trade Commission's 2003 report on innovation and competition and National Research Council's 2004 study of the patent systemboth identified hold-up as a significant problem of the U.S. patent system. ${ }^{54}$ Recent books on the problems with the patent system also identify hold-up and the patent troll as a critical component of the current patent problems. ${ }^{55}$

48 There is, however, some societal value even in a patent being used by a patent troll-value in the information disclosed in the patent itself, for example. See Jeanne C. Fromer, Patent Disclosure, 94 IowA L. REV. 539, 47-550 (2009).

49 See, e.g., Jeremiah Chan \& Matthew Fawcett, Footsteps of the Patent Troll, 10 InTELl. Prop. L. BULl. 1, 5 (2005); Robert P. Merges, Introductory Note to Brief of Amicus Curiae in eBay v. MercExchange, 21 BERKELEY TECH. L.J. 997, 997 (2006).

50 Robert P. Merges \& Richard R. Nelson, On the Complex Economics of Patent Scope, 90 ColuM. L. REV. 839, 907 (using the term "tollkeeper[]" to identify a patentee that does not assist the real world development of the invention but simply takes license revenue for that development).

51 See Brief of Amicus Curiae Yahoo! Inc. in Support of Petitioner at 2-3, eBay Inc. v. MercExchange, L.L.C., 547 U.S. 388 (2006) (No. 05-130).

52 Id. at 6-7.

53 Michael J. Meurer, Controlling Opportunistic and Anti-Competitive Intellectual Property Litigation, 44 B.C. L. REV. 509, 509 (2003); see also Lemley \& Shapiro, supra note 11.

54 See NAT'L RESEARCH COUNCIL, A PATENT SYSTEM FOR THE 21 ST CENTURY (Stephen A. Merrill et al. eds., 2004); FED. TRADE COMM'N, TO PROMOTE INNOVATION: THE PROPER BALANCE OF COMPETITION AND PATENT LAW AND POLICY (2003), http://www.ftc.gov/os/2003/10/innovationrpt.pdf.

55 See, e.g., James BeSSEN \& Michael J. Meurer, Patent Failure: How JUDGES, BUREAUCRATS, AND LAWYERS PUT INNOVATORS AT RISK 160 (2008) (noting that "troll-like" behavior is certainly a problem"); DAN L. BURK \& 


\section{Definitional Problems}

The hunt is on, but it faces a significant hurdle recognized by many-who exactly is being hunted? Some view a patent troll as anyone having certain inherent characteristics - never practicing the patented invention and seeking only to license it. ${ }^{56}$ Others go further with the definition, looking for more specific actions, such as asserting patents against practicing entities when a hold-up situation is highly possible in order to maximize royalties. ${ }^{57}$

It has become difficult to pick a definition that is not overor under-inclusive. For example, as Mark Lemley points out, under an overly broad definition, most universities can be viewed as patent trolls. ${ }^{58}$ Universities rarely, if ever, actually commercialize the patented technology they invent. ${ }^{59}$ Instead, universities seek to transfer their inventions to others and, in the process, may assert patents in the hope of seeking royalties. ${ }^{60}$ Such actions could be defined as the work of a patent troll, but university-originated inventions, purposively spurred in part by the patent system, are seen by most as beneficial, not problematic. $^{61}$

Just like universities, individual inventors can also arguably fall under the umbrella of patent trolls. ${ }^{62}$ Garage inventors do not have the means to commercialize. Their main goal from the beginning, most likely, is to sell their patented technology to a larger company who has the capability to bring it to market. In the process, they may have to assert their patent to obtain such a royalty. These characteristics and actions are part of the individual inventor's narrative, but now they are also part of the patent troll's as well. ${ }^{63}$ According to one definition, a patent troll is "one of a

Mark A. Lemley, The Patent Crisis and How Courts Can Solve It 28-30 (2009).

56 Brenda Sandburg, Trolling for Dollars, LAW.COM, July 30, 2001, http://www.law.com/jsp/PubArticle.jsp?id=900005370205 (describing the term as defined by its creator, Peter Detkin, then assistant general counsel for Intel Corporation).

57 Mark Lemley, Are Universities Patent Trolls?, 18 FORDHAM INTELL. PROP. MEDIA \& ENT. L.J. 611, 630 (2008) ("Instead of singling out bad actors, we should focus on the bad acts and the laws that make them possible. We will solve the troll problem not by hunting down and eliminating trolls, but by hunting down and eliminating the many legal rules that facilitate the capture by patent owners of a disproportionate share of an irreversible investment.").

58 Id. at 629.

59 Id.

60 Id.

61 Id. at 629-30.

62 See, e.g., Andrew Beckerman-Rodau, The Supreme Court Engages in Judicial Activism in Interpreting the Patent Law in eBay, Inc. v. MercExchange, L.L.C., 10 TUL. J. TECH. \& INTELL. PROP. 165, 173 (2007) (“[S]o-called patent trolls are often independent inventors or small startups.").

63 See supra Section II.A. 
class of patent owners who do not provide end products or services themselves, but who do demand royalties as a price for authorizing the work of others." ${ }^{64}$ The same could be said of the individual inventor.

As Ronald Mann puts it, "any effort to design a suitable definition of the term 'troll' is likely to lend credence to the view that the status as a troll is in the eye of the beholder." ${ }^{.65}$ Some individual inventors will introduce real hold-up problems, and thus are legitimately patent trolls. However, a significant number will certainly not. ${ }^{66}$

\section{B. The Patent Troll's Impact on the Individual Inventor Motif}

Given the focus on eradicating the patent troll and the individual inventor's similarities to a patent troll, the individual inventor motif may be in real trouble in modern patent discourse. Has the individual inventor universally become the villainous patent troll or has the motif remained unscathed (or is it sitting somewhere in between)?

This Section attempts to measure the current status of the individual inventor motif in patent law in two ways. First, it examines the usage of individual inventor rhetoric by all three governmental branches to see if the motif is invoked as strongly as it was before the current emphasis on the patent troll. ${ }^{67}$ Second, it examines major patent law changes by the three branches to see if these changes - most seeking to remedy the harms of patent trolls - negatively impact individual inventors. By examining both the rhetorical use and the substantive impact of the motif since the rise of the patent troll, the current status of the individual inventor, at least in the eyes of major government actors, is hopefully clarified.

64 Golden, supra note 9 , at 2112.

65 Mann, supra note 13, at 1023-24 ("It is difficult to discern any principled distinction between the desire of the inventor to appropriate the value of his invention and the desire of operating firms to appropriate the value of their inventions.").

${ }^{66}$ See Marc Morgan, Stop Looking Under the Bridge for Imaginary Creatures: A Comment Examining Who Really Deserves the Title Patent Troll, 17 FED. CIR. B.J. 165, 177 (2008) ("[I]ndividual inventors should not be considered patent trolls. Though they do not produce their innovations, individual inventors are crucial to America's technological growth and account for $18 \%$ or more of the patent filers in the USPTO.").

67 The study performed by this Article can be contrasted to Janis's work. Janis's work covers a perfect, contrasting time frame-right before the reform movement that focuses on patent trolls and the major patent system reports. See Janis, supra note 1, at 913-22. 


\section{Legislative View}

The major modern patent reform bill has been before Congress since $2005 .^{68}$ While the specifics of the legislation proposed over the last four years varies, a majority of the amendments-from damages reform to post-grant opposition mechanisms-are meant to remedy the hold-up/patent troll problem. None of the proposed legislation has passed, with the 2009 version having yet to be passed by either the House or Senate. ${ }^{69}$ The Patent Reform Act of 2007-H.R. 1908 - came the closest to becoming law-passing in the House, but failing in the Senate. ${ }^{70}$ Thus, while there have been no significant legislative changes recently, the discourse surrounding the proposed patent reform bills - particularly H.R. 1908 - as well as their substance, provide insight as to Congress's current view of the individual inventor in the age of the patent troll.

\section{i. Rhetoric}

In general, the discussions surrounding pending patent reform legislation include a very positive individual inventor narrative. No one in Congress during this period questioned the need to support individual inventors or look out for their special concerns. ${ }^{71}$ Discussions of patent trolls and hold-ups were kept distinct and separate from mentions of the small inventor. ${ }^{72}$

In fact, small inventors were affirmatively made a part of the legislative process. Almost every committee meeting on patent reform included a panelist who was herself, or represented, an individual or small inventor. ${ }^{73}$ The House Committee on Small

${ }_{68}$ Patent Reform Act of 2005, H.R. 2795, 109th Cong. (2005).
See Patent Reform Act of 2009, S. 515, 111th Cong. (2009).
70 Patent Reform Act of 2007, H.R. 1908, 110th Cong. (2007).
71 See 153 ConG. REC. H 10,270, 10,301 (2007) (statement of Rep. JacksonLee) (" $[\mathrm{W}] \mathrm{e}$ must always be mindful of the importance of ensuring that small companies have the same opportunities to innovate and have their inventions patented and that the laws will continue to protect their valuable intellectual property.").

${ }^{72}$ See Patent Trolls: Fact or Fiction?: Hearing Before the Subcomm. on Courts, the Internet, and Intellectual Property of the H. Comm. of the Judiciary, 109th Cong. 4 (2006) (statement of Congressman Bass) ("Dean Kamen really works and represents what is the heart of America's economics and industrial future. $\mathrm{He}$ is truly an inventor, and he owns and runs one of the Nation's few really successful modern development labs.").

73 See, e.g., Patent Reform in the 111th Congress: Legislation and Recent Court Decision: Hearing Before the S. Comm. on the Judiciary, 111th Cong. (2009), http://judiciary.senate.gov/hearings/hearing.cfm?id=3701 (including testimony from Taraneh Maghame, vice president of a small company); Patent Trolls: Fact or Fiction?: Hearing Before the Subcomm. on Courts, the Internet, 
Business even had a full committee hearing on the impact of patent reform on small businesses. ${ }^{74}$

The floor debate concerning the 2007 House version of the patent reform legislation - H.R. 1908 - provides a very interesting perspective on the rhetorical use of the individual inventor motif by congress. The legislation before the House contained many provisions that were seen as hostile to small inventors. ${ }^{75}$ H.R. 1908 would switch the U.S. patent system from first-to-invent to first-tofile and provided for automatic publication of all patent applications at eighteen months. ${ }^{76}$ H.R. 1908 also modified the damages provisions and established a post-grant review system. ${ }^{77}$ These provisions were seen by some as providing large companies an unfair advantage in defending against allegations of patent infringement by individual inventors. ${ }^{78}$

Almost everyone who spoke out against the legislation, in particular against the provisions identified above, invoked the individual inventor motif to explain the reason the legislation was harmful. For example, Representative Gohmert argued as follows:

[The legislation must be sponsored by] huge defendants who wanted to drag small entrepreneurs into dilatory situations so that their invention or component could be usurped without proper compensation, even though it might mean the bankruptcy of the inventor and the destruction of the opportunity for the little guys with the inventive vision and spirit, which actually spurred some of the

and Intellectual Property of the H. Comm. of the Judiciary, 109th Cong. (2006) (including the testimony of Dean Kamen, individual inventor).

74 The Importance of Patent Reform to Small Businesses: Before the H. Comm. on Small Business, 110th Cong. (2007).

${ }_{75}$ See, e.g., Adam J. Sedia, Legislative Update: Storming the Last Bastion: The Patent Reform Act of 2007 and Its Assault on the Superior First-to-Invent Rule, 18 DePAUl J. ART, TECH. \& INTELL. Prop. L. 79, 79 (2007) ("The bill, currently on the Senate's legislative calendar and likely to come up for vote soon, faces heavy opposition from several interest groups, particularly small inventors and the biotechnology industry.").

76 Patent Reform Act of 2007, H.R. 1908, 110th Cong. $\S \S 3,9$ (a) (2007).

77 Id. $\S 6$.

78 See, e.g., Darren Cahr \& Ira Kalina, Of PACS and Trolls: How the Patent Wars May Be Coming to a Hospital Near You, 19 HEALTH LAW. 15, 16 n.9 (2006) ("Although large corporations argue in favor of changes that reduce the risks of patent litigation, small inventors criticize proposals that disadvantage individuals trying to enforce their patent rights while these same corporations often have significant intellectual property licensing arms."). 
greatest developments and wealth we know and have in this country. ${ }^{79}$

One House member, Representative Rohrabacher even went so far as to call the legislation the "Steal American Technologies Act."

Those supporting the legislation did not question the need to protect the individual inventor. ${ }^{81}$ Some said that the legislation as proposed would actually help small inventors. ${ }^{82}$ They also addressed these concerns by promising that changes to the legislation were made or were going to be made to address the individual inventors' concerns. ${ }^{83}$ A few supporters went a step further, framing the discussion as one of balancing - a tradeoff between eradicating patent trolls and aiding the small inventor. ${ }^{84}$ But such comments were incredibly sparse and came in a far second to pro-individual inventor commentary from those who supported the legislation.

79153 CONG. REC. H 10,270, 10,278 (2007) (statement of Rep. Gohmert, Member, Crime Subcomm. of the Judiciary Comm.) ("[ $[\mathrm{t} t$ is big companies who do not want others to have the opportunities that they did.").

80 Id. at 10,273-74 (statement of Rep. Rohrabacher) (noting that the legislation "would be a disaster for individual inventors").

81 See id. at 10,276 (statement of Rep. Lofgren) (recognizing the interests of "small inventors"); $i d$. at 10,301 (statement of Rep. Jackson-Lee) ("On the other hand, Mr. Chairman, we must always be mindful of the importance of ensuring that small companies have the same opportunities to innovate and have their inventions patented and that the laws will continue to protect their valuable intellectual property.").

${ }_{82}$ See id. at 10,282 (statement of Rep. Wexler) ("This bill will nurture and protect inventors, thereby promoting future Alexander Graham Bells and tomorrow's Microsofts.").

83 See id. at 10,279 (statement of Rep. Jackson-Lee) ("I am delighted that even though there are questions about, for example, the first-to-file over the first-toinvent, this committee saw fit to add my amendment which means that there will be periodic review so Congress will be instructed on whether or not this works on behalf of all inventors big and small.").

${ }^{84}$ See id. at 10,276 (statement of Rep. Lofgren) ("I represent Silicon Valley, which has a diversity of high tech. Biotech, large companies, small companies, universities, small inventors, pharmaceutical companies, we have got them all, including small inventors working out of a garage. A balanced approach to innovation is essential to all of these entities."); id. at 10,277 (statement of Rep. Johnson) ("In order to continue to stimulate growth and reward inventors in these various sectors, we in Congress are charged with finding the right balances between protecting inventions and stimulating innovation."); id. at 10,280 (statement of Rep. Jackson-Lee) ("Thus, it is very important that we take care not to harm this incubator of tomorrow's technological breakthroughs. The bill before us strikes the proper balance."). 


\section{ii. Substance}

In sharp contrast to the unanimity of the rhetoric, the pending legislation, particularly the H.R. 1908 version of patent reform legislation, would negatively affect individual inventors. Most of the legislation's provisions - particularly damage reforms and the post-grant review provisions-were all provisions that assisted companies to defend against allegations of infringement, particularly allegations by patent trolls. ${ }^{85}$ While such provisions helped those who were defendants in patent suits, the provisions generally hurt those who would be asserting patents. This is especially true for plaintiffs with fewer resources and less sophistication, including small inventors. In addition, given the unlikelihood that they will manufacture or sell products or services, small inventors benefit more from patent strength than they do from laws which make patent defense easier. Aside from its pro-defendant provisions, the legislation also included the aforementioned shifts to first-to-file and automatic publication. Both moves were made to harmonize U.S. patent law with most foreign patent systems, but these provisions were also generally seen as harmful to individual inventors. ${ }^{86}$

The legislation was, however, eventually defeated. The current, 2009 version, which includes similar, albeit not as many, anti-individual inventor provisions has still not passed. ${ }^{87}$ And the provisions that were contained in H.R. 1908 as approved by the House, and more recent versions of the legislation, include compromises to soften the impact on small inventors. ${ }^{88}$ Some of these are changes that were made during the House floor debate of H.R. $1908 .^{89}$ Accordingly, the substantive impact of the patent troll on the individual inventor is currently nil, and the compromises and defeats may evidence the work of the individual inventor motif as continuing to protect small inventors in the patent system. ${ }^{90}$

85 See supra note 77.

86 See supra note 75. But see Karen Simon, The Patent Reform Act's Proposed First-to-File Standard: Needed Reform or Constitutional Blunder?, $6 \mathrm{~J}$. MARSHALl REV. INTELL. PROP. L. 129, 138 n.77 (2006) (noting that the current first-to-invent regime in the United States is "costly" to small inventors because it prompts "large inventors to challenge the patents of small inventors more frequently" by filing interferences).

87 See Patent Reform Act of 2009, S. 515, 111th Cong. (2009).

88 See 153 CONG. REC. H. at 10,297 (statement of Rep. Issa) (offering a floor amendment to the early publication portion of H.R. 1908); see also Patent Reform Act of $2009 \S 7$ (removing the automatic publication requirement).

89 See 153 CONG. REC. H at 10,297.

90 See, e.g., John R. Allison et al., Valuable Patents, 92 GEO. L.J. 435, 468 (2004) (discussing the success of the small inventors lobby). Another explanation, explored more infra Section III.B, is that the changes were made to protect the pharmaceutical industry, not the small inventor. 


\section{Administrative View}

The USPTO's own literature, particularly on its website, provides insight into its current view of individual inventors. The USPTO's response to comments on two recent rule packages also provides indication that the motif is alive and well at the USPTO. This Subsection examines both the rhetoric used by the USPTO regarding individual inventors as well as the substantive impact of its rulemaking.

\section{i. Rhetoric}

The USPTO has continued to describe the individual inventor in a positive light. The USPTO website has an entire section devoted solely to resources for independent inventors. ${ }^{91}$

The USPTO has also espoused positive rhetoric concerning individual inventors in its response to comments on one of the two rule packages it issued in the last couple of years. In the first of the two rule packages, the USPTO issued rules concerning the continuation of patent application filings and claim limitations rules that were set to go into effect at November $1,2007 .{ }^{92}$ The rules essentially limited the number of times a patent applicant could file for continuations of patent prosecution for a single application. ${ }^{93}$ The rules also limited the number of claims per application. ${ }^{94}$

A significant number of the comments received by the USPTO asserted that the rules would have a particularly harmful impact on small inventors, or as the USPTO identifies them, small entities. ${ }^{95}$ The USPTO confronted these comments head-on. They

91 U.S. Patent \& Trademark Office, Independent Inventors, http://www.uspto .gov/inventors/independent/index.jsp (last visited Dec. 16, 2009).

92 See Changes to Practice for Continued Examination Filings, Patent Applications Containing Patentably Indistinct Claims, and Examination of Claims in Patent Applications, 72 Fed. Reg. 46,716 (Aug. 21, 2007) (to be codified at 37 C.F.R. pt. 1). Due to litigation over the validity of the rules, the effective date, if they ever become effective, is still uncertain. See Tafas v. Doll, 559 F.3d 1345, 1364-65 (Fed. Cir. 2009) (finding the claim limitation rules valid, and the continuation rules invalid because they conflicted with 35 U.S.C. $\S 120$ (2006), and remanding the case to the district court).

93 See Changes to Practice for Continued Examination Filings, 72 Fed. Reg. at 46,716-17 (revising 37 C.F.R. $\S 1.78$, pertaining to continuations, and 37 C.F.R. $\$ 1.114$, pertaining to requests for continued examination).

94 See id. (revising 37 C.F.R. $\S 1.75$, limiting the total number of claims per application to no more than five independent claims and twenty-five total claims, and 37 C.F.R. $\S 1.265$, describing the examination support document needed to be submitted to go beyond these limitations).

95 See id. at 46,743-44, 46,745, 46,754, 46,758, 46,759-60, 46,763, 46,765-66, $46,783,46,788,46,793,46,798,46,801,46,811,46,824,46,828$ (containing comments concerned with the proposed rules' impact on small entities). A small 
did not dispute the underlying premise that small inventors' concerns were worth addressing. Instead, they answered whether the rules would have a negative impact on individual inventors and whether such concerns needed addressing. ${ }^{96}$ The USPTO also articulated the overall purpose of the rules as inventor-neutral. ${ }^{97}$ The USPTO stated that the rules are meant to reduce examination backlog and improve the quality of examination across the board, not to address the patent hold-up problem, or, more specifically, the patent troll problem. ${ }^{98}$

\section{ii. Substance}

The USPTO continues to adjust filing fees based on the filing entity's size. ${ }^{99}$ Small entities still have their fees essentially cut in half as compared to other applicants. ${ }^{100}$ The rationale is that higher fees uniquely bar individual inventors' access to the patent system because of their lack of resources. ${ }^{101}$ The adjustment of filing fees is meant to equalize access to the patent system between large and small inventors. In addition to these fee adjustments, the USPTO also made changes to the two recent rule packages to address substantive concerns of individual inventors.

One of the main substantive concerns with the continuation rule package was that limiting the continuations available would harm small inventors. This is because such inventors are both more likely to file continuations and have fewer resources to effectively obtain adequate patent rights when continuations are limited. ${ }^{102}$ Individual inventors need patents earlier in the development process to secure investment. Thus, they need to separate earlier allowed claims and then continue prosecution on still-rejected claims. In addition, small inventors often cannot spend as much up front, and thus need continuations to spread out their application

entity, as defined by the USPTO, includes a "person, small business concern, or nonprofit organization." 37 C.F.R. $\S 1.27$ (2008).

96 See id. at 46,743-44, 46,745, 46,754, 46,758, 46,759-60, 46,763, 46,765-66, $46,783,46,788,46,793,46,798,46,801,46,811,46,824,46,828$.

97 See, e.g., id. at 46,760 ("The changes being adopted in this final rule [37 C.F.R. $§ 1.78]$ do not disproportionately impact small entities.").

98 See Tafas v. Doll, 559 F.3d 1345, 1350 (Fed. Cir. 2009); Changes to Practice for Continued Examination Filings, 72 Fed. Reg. 46,716.

99 See 37 C.F.R. $§ 1.16$ (a)(1) (setting forth the filing fee for both a regular applicant and a small entity).

${ }^{100} \mathrm{Id}$.

${ }^{101}$ See Mike R. Turner, Note, The Future of the Corroboration Requirement in Patent Law: Why a Clear, Strict Standard Benefits All, 2008 U. ILL. L. REV. 1319,1344 ("[T] the patent office on small entities.").

${ }^{102}$ Changes to Practice for Continued Examination Filings, 72 Fed. Reg. at $46,759,46,765-66$. 
costs. ${ }^{103}$ The package also addressed the argument that small entities simply make up the majority of continuation filings. ${ }^{104}$

The USPTO responded to these comments, as well as those from other types of inventors, by relaxing the limitation on continuations. ${ }^{105}$ As compared to the initially proposed rules, instead of one continuation, an applicant could now file two as a matter of right. To obtain further time, an applicant could in addition file a request for continued examination. Furthermore, as the USPTO pointed out, small inventors can file even more continuations than these, they just have to meet the justification criteria. ${ }^{106}$

The USPTO also did a study to examine the substantive impact of the continuation limitations on small inventors. The USPTO found that $2.9 \%$ of applications filed by small inventors included enough continuations to require special justification under the new rules. ${ }^{107}$ This was in comparison to a slightly lower rate, $2.7 \%$, for all patent applications. ${ }^{108}$

There was also concern about the continuation rules' requirement that divisional applications be filed during the pendency of the initial application. ${ }^{109}$ Small inventors would not be able to spread out their prosecution costs over the sequential filing of divisional applications, particularly as aspects of the invention became commercially viable. The USPTO responded by amending the rules to allow for sequential filing of divisionals. ${ }^{110}$

Finally, there was also an argument that the limitation on the number of claims available under the continuation rules would harm small inventors. ${ }^{111}$ Individual inventors may need more claims than the average inventor to provide adequate protection for their inventions, and cannot pay the financial and procedural price

103 Id. (reporting comments asserting that "the rule changes could stifle the building of patent portfolios for small companies and cause a reduction of capital investment in these companies and in new technologies").

104 Id.

${ }^{105}$ Id. at 46,759 ("The Office has made modifications to these proposed changes such that this final rule will permit an applicant to file two continuation applications or continuation-in-part applications, plus a single request for continued examination in an application family, without any justification.").

${ }^{106} I d$. at 46,745 (noting that if an applicant wishes to pursue more than two continuation applications, he must file a petition "showing that the amendment, argument, or evidence sought to be entered could not have been submitted during the prosecution of the prior-filed application.").

${ }^{107}$ Id. at 46,760 .

108 Id.

109 Id. at 46,745 .

${ }^{110}$ Id. ("In response to those concerns and suggestions, [37 C.F.R.] $§ 1.78$ (d)(ii) as adopted in this final rule does not require that a divisional application be filed during the pendency of the initial application.").

111 Id. at 46,765-66. 
of meeting the special requirement under the rules to get more claims. $^{112}$

The USPTO responded by changing the proposed rules to allow for more claims to be filed than originally suggested. ${ }^{113}$ The USPTO also studied the filings of small entities and found that $24.4 \%$ of the cases would exceed the amended limitation on claims, as compared to a $23.7 \%$ for all applicants. ${ }^{114}$ The difference in impact did not appear to be disparate between applicants as a general population and the individual inventors. Finally, small entities could file an examination support document ("ESD") in order to obtain claims beyond those initially allowed. $^{115}$ And the USPTO specifically amended the rules to make this less burdensome on small entities, with $\S 1.256(\mathrm{f})$ removing the most onerous part of the ESD, the requirement to apply prior art to the proposed claims and articulate why the claims are allowable over that art, exclusively for small entities. ${ }^{116}$

There were also substantive concerns regarding the second, more recent rule package that contained procedural changes to filing appeals to the Board of Patent Appeals and Interferences. ${ }^{117}$ There was discussion about whether the rules added an additional filing cost that would significantly impact small inventors. ${ }^{118}$ This debate arose not so much in response to comments, but from the USPTO's discussion in response to the requirements of the Regulatory Flexibility Act. ${ }^{119}$ After making some assumptions about the number of individual inventor applicants that would exceed the space limitations, the USPTO concluded that the impact would be small and further change unnecessary. ${ }^{120}$

112 Id

113 Id. at 46,788 .

114 Id.

115 Id.

116 Id. at 46,798, 46,743-44 (noting that this inclusion was also in response to the Regulatory Flexibility Act); see also id. at 46,798 ("A number of comments argued that the search and analysis necessary to prepare an examination support document would add significant cost to the preparation of an application, that the cost would be significantly more than the $\$ 2,500$ predicted by the Office, and that this would significantly disadvantage independent inventors and small businesses.").

117 See Rules of Practice Before the Board of Patent Appeals and Interferences in Ex Parte Appeals, 73 Fed. Reg. 32,938 (June 10, 2008) (to be codified at 34 C.F.R. pt. 41).

118 Id. at 32,972 .

$119 I d$. at 32,969. Section 603 of the Regulatory Flexibility Act requires administrative agencies to analysis the costs of regulations to small businesses and consider alternatives to reduce the impact on such small businesses. 5 U.S.C. $\S 603$ (2006).

${ }^{120}$ Rules of Practice Before the Board of Patent Appeals, 73 Fed. Reg. at 32,972 ("When [the assumption of the number of applicants going over the page limit] is compared to the 5,977 small entities that filed a notice of appeal with the 


\section{The Individual Inventor Motif In THE Age of THE PATENT TROLL}

\section{Judicial View}

While the Federal Circuit is usually the first judicial body that comes to mind when discussing patent law, ${ }^{121}$ there has been a significant amount of patent law activity at the Supreme Court during the patent troll era. Seven opinions on significant patent law areas have issued over the past four years. ${ }^{122}$ And in almost every single one, amicus briefs were filed asserting that individual inventor's interests were at stake. Accordingly, the following analysis focuses on the Supreme Court and looks at both the rhetoric in, and substantive effect of, these decisions concerning the individual inventor. ${ }^{123}$

\section{i. Rhetoric}

In only one patent case out of the eight issued since 2003 has the Court explicitly mentioned the individual inventor. In eBay, Inc. v. MercExchange, L.L.C., the Supreme Court held that the general four-factor test for determining whether a permanent injunction should issue must be used in patent cases. ${ }^{124}$ Under the

Office in FY 2007 (21,653 notices of appeal were filed by large entities in the same period), it demonstrates that the petition fee has the potential to affect only $2.8 \%$ of the small entities filing an appeal. An effect on $2.8 \%$ of the small entities filing an appeal is not a disproportionate impact on small entities, nor is the actual number of 166 impacted small entities a substantial number.").

121 See John M. Golden, The Supreme Court as "Prime Percolator": A Prescription for Appellate Review of Questions of Patent Law, 56 UCLA L. REV. 657 (2009); Mark D. Janis, Patent Law in the Age of the Invisible Supreme Court, 2001 U. ILL. L. REV. 387.

${ }^{122}$ See Quanta Computer, Inc. v. LG Elecs., Inc., 128 S. Ct. 2109 (2008); Microsoft Corp. v. AT\&T Corp., 550 U.S. 437 (2007); KSR Int'1 Co. v. Teleflex Inc., 550 U.S. 398 (2007); MedImmune, Inc. v. Genentech, Inc., 549 U.S. 118 (2007); Lab. Corp. of Am. Holdings v. Metabolite Labs., Inc., 548 U.S. 926 (2006); eBay Inc. v. MercExchange, L.L.C., 547 U.S. 388 (2006); Ill. Tool Works Inc. v. Indep. Ink, Inc., 547 U.S. 28 (2006).

123 Interestingly, there was little mention of the individual inventor by the Federal Circuit over the last five years. A search was done on the CTAF database on Westlaw-("small inventor" "small inventors" "small entity" "individual inventor" "individual inventors" "individual inventor" "individual inventors" "entrepreneur" "entrepreneurs" "small entities" "small business" "small businesses" "garage inventor" "garage inventors" "start-up" "self-made inventor") \& da(last 5 years) \& patent!-and only one case included a discussion related to the individual inventor motif, in Voda v. Cordis Corp., 536 F.3d 1311, 1329 (Fed. Cir. 2008), where the Federal Circuit dismissed Voda's argument that the denial of a permanent injunction to Voda conflicted with the provision permitting "self-made inventor[s]" to obtain injunctions in the Supreme Court's eBay holding.

124547 U.S. 388. 
facts of the case, there was a question as to whether non-practicing entities could obtain permanent injunctions. ${ }^{125}$

In the Court's decision, the majority rejected the categorical rule that all patentees who are both willing to license and are not commercially practicing their patents should not be awarded injunctions. The Court identified "university researchers" and "self-made inventors" as those who "may be able to satisfy the traditional four-factor test." 126 The Court essentially stated that the "self-made inventor[]"- the individual inventor-could still obtain an injunction after the $e$ Bay decision.

One of the concurrences also focused on the type of patent holder seeking an injunction. That concurrence, authored by Justice Kennedy and joined by Justices Stevens, Souter, and Breyer, ${ }^{127}$ indicated that district courts should take note of "the nature of the patent being enforced and the economic function of the patent holder," and in eBay, the function of the patent holder was "quite unlike earlier cases," presumably because it involved a business method patent and, arguably, a patentee who was only trying to license the patent, not commercialize it. ${ }^{128}$ The concurrence identified the existence of industries where firms use patents mainly to obtain licensing fees. Injunctions in these instances "can be employed as a bargaining tool to charge exorbitant fees to companies that seek to buy licenses to practice the patent." ${ }^{\prime 29}$ In this context, the concurrence discussed the patent hold-up problem, noting that " $[\mathrm{w}] \mathrm{hen}$ the patented invention is but a small component of the product the companies seek to produce and the threat of an injunction is employed simply for undue leverage in negotiations, legal damages may well be sufficient to compensate for the infringement and an injunction may not serve the public interest." ${ }^{\prime 30}$ Justice Kennedy's concurrence focused on patentees that exhibit patent troll-like characteristics, concluding that injunctions should not be available to such individuals.

The majority took a neutral view of the individual inventor - telling district courts not to immediately conclude that a small inventor does not deserve an injunction. ${ }^{131}$ The majority did not, however, go so far as to require that all individual inventors receive an injunction-like large firms, they have to satisfy the four factor test. However, the concurrence authored by Justice Kennedy muddled this message by focusing on the patent troll.

${ }^{125} \mathrm{Id}$. at 393.

${ }^{126} \mathrm{Id}$.

${ }^{127} I d$. at 396-97 (Kennedy, J., concurring).

${ }^{128}$ Id.

${ }^{129} I d$. at 396.

${ }^{130} \mathrm{Id}$. at 396-97.

${ }^{131} I d$. at 393 (majority opinion). 
The concurrence encouraged district courts to watch out for patent hold-up situations, caused by patent holders just looking to monetize their patents. These cases, involving non-practicing entities using patents solely for monetary purposes, signify the rise of the patent troll problem, not seen in the "earlier cases." 132 In the concurrence's view, the focus is on removing the unfair advantages injunctions give to some non-practicing entities who seek to license - a category of patentee that is commonly comprised of individual inventors.

\section{ii. Substance}

When comparing the majority decision in eBay to Justice Kennedy's concurrence, the Court's rhetorical use of the individual inventor motif is inconclusive at best. The substantive story, however, is a bit clearer. Almost all of the Court's recent patent decisions have reached holdings that are detrimental to individual inventors. The main reason this is the case is that all of the decisions essentially weaken patent rights, and it's the patent right - not the shielding from accusations of patent infringementthat benefits individual inventors the most. ${ }^{133}$

For example, while the majority in eBay expressly indicated that "self-made inventors" should not be uniquely harmed by the Court's decision, ${ }^{134}$ this rhetoric has not stopped lower courts from denying injunctions to individual inventors. In fact, that language has been cited and then dismissed in a majority of cases denying injunctions to small inventors. ${ }^{135}$ This is because the four-factor test for an injunction places small inventors at a disadvantage, particularly when read in light of Justice Kennedy's concurrence. As John Golden summarizes it:

Despite the unanimous Court's warning against "certain expansive principles suggesting that injunctive relief could not issue in a broad swath of cases," district courts have responded in apparent lockstep to Justice Kennedy's concerns about trolls. Since the Supreme Court issued its opinion in eBay, district courts appear to have consistently denied permanent injunctions in cases where an infringer has contested the patent holder's request for such

${ }^{132} I d$. at 396 (Kennedy, J., concurring).

133 But see BESSEN \& MEURER, supra note 55, at 173-77 (concluding that patents are not as valuable to individual inventors as other methods of appropriating value from their innovation).

${ }^{134} 547$ U.S. at 393.

135 See, e.g., Voda v. Cordis Corp., 536 F.3d 1311, 1329 (Fed. Cir. 2008). 
relief and the infringer and patent holder were not competitors. ${ }^{136}$

Golden continues in his analysis by noting that "[s]ystematically curtailing injunctive relief for such patent holders may inflict injury on patent trolls, but it may also victimize those classes of inventors whom patent law should be most careful to protect." ${ }^{\prime 137}$ The class he is referencing includes individual inventors.

Many other recent patent decisions by the Court seem to come out against positions advocated for by individual inventors. For example, in Microsoft Corp. v. AT\&T Corp. ${ }^{138}$ the Court held that 35 U.S.C. $\S 271(\mathrm{f})$, while making the combination of a patented invention outside the United States actionable infringement in some cases, does not cover the sending of software from the United States to a foreign manufacturer who uses the software to make a U.S. patented invention abroad. The argument by small companies and universities was that holding such activity not to be infringement created a loophole that corporations like Microsoft could take advantage of. ${ }^{139}$ Companies with foreign ties would be able to send their manufacturing abroad to avoid infringement, and could avoid liability for stealing a less powerful entity's invention that way. ${ }^{140}$

The Supreme Court's decision in MedImmune, Inc. v. Genentech, Inc. ${ }^{141}$ disadvantages individual inventors because the decision makes it easier for potential infringers-those who individual inventors will enforce their patents against - to avoid contractual obligations and forum shop. In MedImmune, the Supreme Court concluded that a licensee can challenge the licensed patent's validity without terminating or breaching the underlying license. ${ }^{142}$ The result of this holding also lowered the bar as to what creates an "actual controversy" for the purposes of sparking a valid declaratory judgment action, essentially allowing alleged infringers to control forum selection in patent suits by allowing them to file declaratory judgment actions even before

${ }^{136}$ Golden, supra note 9, at 2113 (footnotes omitted); see also id. at 2113-14 ("Thus, the district courts' post-eBay practice may be in some tension with the Supreme Court's warning against the "categorical denial of injunctive relief' to broad classes of patent holders.").

${ }^{137}$ Id. at 2160.

138550 U.S. 437 (2007)

${ }^{139}$ See Brief of Amicus Curiae Wis. Alumni Research Found. et al. at 5-6, Microsoft Corp., 550 U.S. 437 (No. 05-1056).

${ }^{140} \mathrm{Id}$.

${ }^{141} 549$ U.S. 118 (2007).

${ }^{142}$ Id. at 119-23. 
breaching the license. ${ }^{143}$ Such a result, as some amici argued to the Supreme Court, "erode[s] the sanctity of contracts and interfere[s] with vital policies favoring amicable resolution of commercial matters" that are so crucial for patentees who depend on royalty streams to monetize their patents. ${ }^{144}$ It also puts small inventors, who would normally be looking for licenses as opposed to overtly seeking out litigation, at a disadvantage to large corporations who can take advantage of the forum advantages that filing early declaratory judgment actions present. ${ }^{145}$

Individual inventors are also disadvantaged by the Court's decision in KSR International Co. v. Teleflex Inc. ${ }^{146}$ because the case's change to the nonobviousness requirement makes patentability determinations unpredictable. The KSR decision rejected a "rigid" test for nonobviousness and replaced it with a "flexible" and "functional" approach. ${ }^{147}$ Some argued that such a shift would render most significant individual inventors' inventions obvious. ${ }^{148}$ "While large business may be only slightly impacted" by the hindsight the Court's test introduces, "small business concerns and struggling innovators [would be] certain to face an instant and devastating diminishment of corporate value." 149 Others asserted that a flexible nonobviousness requirement would make it more difficult for individual inventors to secure financing for their research and development because "potential investors cannot evaluate the likelihood that the venture's pending patent applications will be approved or that its issued patents will be enforced." 150

${ }^{143}$ SanDisk Corp. v. STMicroelectronics, Inc., 480 F.3d 1372, $1377-79$ (Fed. Cir. 2007).

${ }^{144}$ See Brief of Amici Curiae The Trustees of Columbia Univ. in the City of N.Y. et al. at 2, MedImmune, 549 U.S. 118 (No. 05-608).

${ }^{145}$ Even before MedImmune, courts were concerned about the advantages an alleged infringer might have if the requirements for filing declaratory judgment actions were relaxed in patent cases. See, e.g., Fresenius USA, Inc. v. Transonic Sys., Inc., 207 F. Supp. 2d 1009, 1012-13 (N.D. Cal. 2001) ("Exercising jurisdiction over declaratory-relief actions under [expanded] circumstances would create a strong disincentive for patentees to communicate with potential infringers before filing suit, for fear of being sued first and thus forced to litigate in the defendant's forum of choice.").

146550 U.S. 398 (2007).

${ }^{147}$ Id.

148 Brief of Harold W. Milton, Jr. as Amicus Curiae in Support of Respondent at 2, KSR Int'l, 550 U.S. 398 (No. 04-1350) (stating that the inventions of inventors like the Wright brothers and Thomas Edison might be rendered obvious in hindsight).

${ }^{149}$ Brief of the United Inventors Association as Amicus Curiae in Support of the Respondents at 2, KSR Int'l, 550 U.S. 398 (No. 04-1350).

${ }^{150}$ Brief of Altitude Capital Partners et al. as Amici Curiae in Support of Respondents at 4, KSR Int'l, 550 U.S. 398 (No. 04-1350) ("Similarly, a firm like Altitude Capital Partners will be less inclined to back an independent inventor, 
In Quanta Computer, Inc. v. LG Electronics, Inc., ${ }^{151}$ the Court's holding is detrimental to individual inventors because it limits their ability to license their patents effectively. The Court in Quanta determined that a license with a computer components manufacturer exhausted patent rights against purchasers of such components who used them to make, without an expressed license, a patented system and perform a patented method. ${ }^{152}$ Multiple amici argued that tiered licensing, which the decision in Quanta now makes more difficult, is a crucial vehicle by which small inventors recoup their costs of inventing. ${ }^{153}$ Small inventors also rely on others to manufacture and distribute their product because they do not have the capabilities or resources in-house. ${ }^{154}$

\section{III.IMPLICATIONS}

The rhetoric regarding individual inventors remained extremely positive in both Congress and the USPTO. Both of these bodies also at least proposed substantive changes that took individual inventors' interests into account, even if they were not overtly pro-individual-inventor proposals. The USPTO changed its proposed rules to take the concerns of individual inventors into consideration, even creating a special exception for small entities in its claim limitation rules. Although Congress never passed any significant patent legislation during the period studied, it did seriously consider changes that would be harmful to small inventors. The proposed legislation, however, was modified, in some respects, to take at least some of the small inventor's' interests into account. The judiciary essentially did not take any notice of individual inventors' concerns - either on a rhetorical or a substantive level. The Supreme Court's recent decisions did, however, reduce the value of patents, particularly for individual inventors. The following table summarizes these results:

or will do so only on much less favorable terms that diminish incentives to innovate, if Altitude cannot predict with reasonable confidence whether the inventor's patents will be upheld in court.").

15128 S. Ct. 2109 (2008).

${ }^{152} \mathrm{Id}$.

${ }^{153}$ See Brief for Wi-LAN Inc. as Amicus Curiae Supporting Respondent at 1922, Quanta, 128 S. Ct. 2109 (No. 06-937); Brief of Amici Curiae Interdigital Communications, LLC \& Tessera, Inc. in Support of Respondent at 12, Quanta, 128 S. Ct. 2109 (No. 06-937); Brief of Amberwave Systems Corp. as Amicus Curiae in Support of Respondent at 10, Quanta, 128 S. Ct. 2109 (No. 06-937).

${ }^{154}$ Brief for Wi-LAN Inc., supra note 153, at 19. 
Table 1. Patent Troll-Era Handling Of Individual INVENTORS

\begin{tabular}{|l|l|l|}
\hline & Rhetoric & Substance \\
\hline Legislative & Positive & Mixed \\
\hline Administrative & Positive & Positive \\
\hline Judicial & Non-existent ${ }^{155}$ & Negative \\
\hline
\end{tabular}

The following section looks at the implications of these results.

\section{A. Resilience of the Motif's Rhetoric}

When the rhetoric observed by Janis shortly before the modern patent reform efforts and the focus on the patent troll is compared to the rhetoric examined in Section II.B, one can see that not much has changed at all. Congress still engages heavily in the individual inventor rhetoric. ${ }^{156}$ The USPTO is still the strongest ally of the individual inventor. ${ }^{157}$ And litigants continue to invoke the rhetoric in litigation, while the courts, maybe even less so now, do not seem to engage the motif at all. ${ }^{158}$

Other than perhaps the slight drop off by the courts, the individual inventor motif remains rhetorically intact-at least as much as it was before the advent of the patent troll. Those primarily engaged in the usage of rhetoric - mainly Congress and the USPTO - are able to keep the small inventor and the patent troll separate. ${ }^{159}$ The definitional concerns the patent troll hunt presents for the individual inventor motif are not justified. The garage inventor is still a narrative that policymakers find worth telling.

\section{B. Lack of Substance Behind the Motif}

It has been suggested before, most recently by Meurer, that while the motif is strong, there is very little doctrine, or laws for that matter, that are specifically designed to benefit the individual

155 The Court in eBay Inc. v. MercExchange, L.L.C. does mention "self-made inventors." 547 U.S. 388, 393 (2006). Justice Kennedy's concurrence focuses on patent trolls, but not necessarily individual inventors. Id. at 396 (Kennedy, J., concurring). However, the majority's discussion is still neutral and mentions individual inventors sparingly - it does not establish a pro-individual-inventor view of injunctions. And Justice Kennedy never discusses the size of the patent trolls he is focused on, so whether he is considering the individual inventor in his analysis is unclear.

${ }^{156}$ See supra Subsection II.B.1.a.

${ }^{157}$ See supra Subsection II.B.2.a.

${ }_{158}^{15}$ See supra Subsection II.B.3.a.

${ }^{159}$ See supra Subsections II.B.1.a, II.B.2.a. 
inventor. ${ }^{160}$ Other than a few patent rules, there are no positive laws protecting individual inventors. ${ }^{161}$ The Congress attempts to stay, at best, neutral and simply avoid passing laws that disadvantage individual inventors. ${ }^{162}$ Arguably, the Supreme Court tried to do the same in eBay, albeit perhaps unsuccessfully. ${ }^{163}$ Although the rhetoric is still employed, there is just no substance standing behind it. Other than the USPTO reducing some of the application filing burden on small inventors, there is little else that the patent system does to assist such individuals or address their concerns specifically.

In fact, most of the patent law changes either proposed or actually made, mainly in the courts, have come out against individual inventors" interests. The provisions still being discussed in Congress focus on providing defendants with recourse to combat infringement actions, and are thus opposed by small inventor interest groups. ${ }^{164}$ The same, anti-individual inventor effect can be found in recent Supreme Court decisions, with each recent patent decision making it more difficult to successfully enforce patent rights. ${ }^{165}$ Thus, while the rhetoric remains strong, the emptiness of it is self-evident. The troll hunt may have not damaged the individual inventor's image, but it certainly has created substantive changes that cut against small inventors.

The House debate over H.R. 1908 epitomizes the emptiness of the individual inventor motif. Opponents of the bill focus solely on the bill's impact on the small inventor. ${ }^{166}$ And proponents, unwilling to verbally attack the individual inventor, played along rhetorically despite the fact that the law they were supporting made substantive changes that were potentially adverse. ${ }^{167}$ What makes this exchange even more interesting is that the real substance of the debate was probably not big business versus the little inventor, but the information technology industry versus pharmaceutical companies. ${ }^{168}$ And the opposition to the bill—supported mostly by big pharma-did not harp on the legislation's impact on the

\footnotetext{
${ }^{160}$ See Meurer, supra note 1, at 1202-03.

${ }^{161}$ See supra note 103.

${ }^{162}$ See supra Subsection II.B.1.b (describing Congress's recent patent lawmaking efforts).

${ }^{163}$ Golden, supra note 9, at 2113-14.

${ }^{164}$ See Patent Reform Act of 2009, S. 515, 111th Cong. (2009).

${ }^{165}$ See supra Subsection II.B.3.b (cataloging these decisions).

${ }^{166}$ See supra text accompanying notes 79-84.

${ }^{167}$ See supra text accompanying note 86.

${ }^{168}$ See Meurer, supra note 1, at 1214 ("Recent discussions of patent reform emphasize the disparate interests of the pharmaceutical and biotechnology industries on one side, and the information and communication technology industries on the other. Some of the discussion also notes tension between small inventors and big information and communications technology firms.").
} 
pharmaceutical industry, but on the individual inventors. It is highly unlikely that the small inventor was the main concern of opponents, but at least externally that is how it appeared. ${ }^{169}$ Pharmaceutical companies have an interest in stronger patent laws, and since this interests aligned with those of individual inventors, which also commonly benefit from stronger patent laws, pharma found a friend. ${ }^{170}$ The motif was an empty vessel that could dress up the concerns of another, perhaps less sympathetic interest group. ${ }^{171}$ Presumably, if the interests of another powerful industry lined up with those of individual inventors, that industry would utilize the rhetoric of individual inventors for the same reason.

Looking at the recent discourse involving individual inventors shows that it truly is only a rhetorical motif, and not much more, particularly outside the USPTO. Essentially, the motif invokes a very powerful narrative - a story that almost all Americans understand, ${ }^{172}$ but one that does not drive dramatic substantive change, particularly substantive change in favor of individual inventors. ${ }^{173}$ Instead, the motif is co-opted - particularly in Congress - by those parties whose interests are best furthered by policies that strengthen patent rights.

\section{Roles of the Different Institutions in Patent Law}

How different institutions have handled individual inventors' interests, particularly in the age of the patent troll, illustrates a great deal about the role of various institutions in patent law.

The USPTO has been the most receptive to the rhetorical use of the individual inventor motif and actually substantively acted upon it, modifying proposed rules to give individual inventors specific exemptions. ${ }^{174}$ Such a result makes sense from an institutional perspective for a number of reasons. First, the USPTO engages patentees almost exclusively on the patent

\footnotetext{
${ }^{169} I d$.

${ }^{170}$ See Jay P. Kesan \& Andres A. Gallo, The Political Economy of the Patent System, 87 N.C. L. REV. 1341, 1353 (2009) ("Other sectors, for example, biotechnology and pharmaceutical companies, which depend heavily on patents to support their R\&D projects and sustain their market positions, will prefer a strong patent system to foster market value for their innovations.").

${ }^{171}$ See Janis, supra note 1, at 911 ("One might expect patent reformers to be drawn to the strategy of reconceptualizing the reform debate by attempting to couple technical reform measures with the romantic imagery of the lone inventor struggling against a recalcitrant bureaucracy.").

${ }^{172}$ Id. (" $[\mathrm{T}]$ he heroic inventor motif, with its overtones of Jeffersonian selfreliance and Yankee ingenuity, may simply mesh uniquely well with the American perception of its own identity.").

${ }^{173}$ See supra Section II.B.

${ }^{174}$ See supra Subsection II.B.2.
} 
acquisition side of the equation. The USPTO focuses on when individuals should, and should not, obtain patent rights. ${ }^{175}$ This turns out to be the side of the patent system that individual inventors engage most. It is also the side the motif focuses on - the ability of individual inventors to create ground-breaking inventions. The motif should have the most impact on the frontend of patent law, and thus the USPTO. Second, the USPTO's receptiveness to the motif also exemplifies the customer service nature of the agency. ${ }^{176}$ Finally, there are larger pro-small business attitudes at play when considering administrative agency. For example, the Regulatory Flexibility Act is focused solely on helping small businesses interact with regulatory agencies like the USPTO. ${ }^{177}$ In both responses to comments on the recently proposed rules, many of the USPTO's responses to individual inventors' concerns were in response, in part, to the USPTO's duty under the Act.

This individual-inventor-friendly environment at the USPTO sits in sharp contrast to the judiciary's ambivalence to individual inventors' concerns. Every time individual inventors came up in the briefs, except arguably in eBay, the Supreme Court ignored them in the Court's ultimate decision. ${ }^{178}$ This makes sense from an institutional perspective given the law that governed each of those cases made no special exceptions for small inventors. In fact, nothing within the Patent Act treats such inventors differently. ${ }^{179}$ Given that overt direction, or lack thereof, by Congress, courts, as they arguably should, address only those concerns identified by legislators. The Supreme Court's handling of the motif evidences restraint, a lack of judicial activism, for want of a better term. ${ }^{180}$ The judiciary's failure to consider the

175 See Stuart Minor Benjamin \& Arti K. Rai, Who's Afraid of the APA? What the Patent System Can Learn from Administrative Law, 95 GEO. L.J. 269, 27677 (2007) ("Instead of asking whether a given patent is necessary to promote innovation, the patent statute directs the PTO to determine whether the patent application meets validity standards that have scientific and technical underpinnings.").

${ }^{176}$ See Rochelle Dreyfuss, Pathological Patenting: The PTO as Cause or Cure, 104 MiCH. L. REV. 1559, 1567 (2006) (reviewing ADAM B. JAFFE \& JOSH LERNER, INNOVATION AND ITS DISCONTENTS: HOW OUR BROKEN PATENT SYSTEM IS ENDANGERING INNOVATION AND PROGRESS, AND WHAT TO DO ABOUT IT (2004)) (“[T]he PTO's profit orientation disposes it to grant its customer/clients' patents. Nor are these patents invalidated when they get to court.").

177 See 5 U.S.C. $\S \S 601-612(2006)$.

178 See supra Subsection II.B.3.b.

179 See Meurer, supra note 1, at 1202-03.

${ }^{180}$ Giacomo A.M. Ponzetto \& Patricio A. Fernandez, Case Law Versus Statute Law: An Evolutionary Comparison, 37 J. LEGAL STUD. 379, 393-94 (2008) (setting forth a definition of judicial activism). 
motif is the way it is supposed to work - with the courts immune to rhetoric and popular opinion, particularly popular opinion that is not expressed in any specific statutory provision. ${ }^{181}$ This reason for the general absence of the motif seems especially likely given the court's language in $e B a y$. The case discusses the application of equitable remedies, an area in which courts are least constrained by statute. And $e B a y$ is the only case in which the individual inventors' interests made their way into the opinion. ${ }^{182}$

The motif's lack of influence on the judiciary is also a product of the fact that, while the USPTO is on the front end, courts are, for all intensive purposes, on the back end of the patent system. They see the patented invention in the context of a lawsuit in which an allegedly infringing defendant has produced her own product or service. ${ }^{183}$ This context is also the one where the impact of patent trolls is most noticed, because in those cases, the plaintiffs have produced nothing. ${ }^{184}$ Sometimes it is also the context in which the individual inventor is not the only innovator, particularly since most cases involve a defendant that did not copy the invention, giving them some moral ground. ${ }^{185}$ That is, the defendant is likely to have gone through the complete invention and development process themselves and simply come in second, behind the first to invent. ${ }^{186}$ The motif is, therefore, at its weakest at the enforcement stage and perhaps most susceptible to being ignored.

Finally, Congress's handling of the individual inventor motif makes sense. Congress sits in the middle of these issueswith individual inventors needing to be protected on the front end and patent trolls thwarted on the back end. Congress also is more likely to engage in rhetoric, particularly rhetoric its constituents understand and support. ${ }^{187}$ And rhetoric that, in the end, turns out to be empty.

\section{Conclusion}

These findings have tremendous import for the individual inventor motif and the patent system in general. The individual inventor motif has been around for a long time and has

\footnotetext{
${ }^{181} I d$.

18235 U.S.C. $\& 283$ (indicating that district courts "may grant injunctions"); eBay v. MercExchange, 547 U.S. 388, 389 (2006).

18335 U.S.C. $\S 281$ (giving a patentee a remedy of a "civil action for infringement of his patent").

${ }^{184}$ See supra Subsection II.A.1.

${ }^{185}$ Christopher A. Cotropia \& Mark A. Lemley, Copying in Patent Law, 87

N.C. L. REV. 1421 (2009).

${ }^{186}$ Id.

${ }^{187}$ See Janis, supra note 1 , at 911.
} 
continuously been invoked in patent discourse. At least in its modern form, the motif has maintained its rhetorical strength in spite of the current negative focus on patent trolls. The prevalence of individual patent holders whose sole focus is to license their patents, not commercialize the underlying technology, so-called patent trolls, has not discouraged usage of the classic American story of the individual inventor.

However, there are very few substantive changes that match the more extensive usage of strong, pro-individual-inventor rhetoric. Individual inventors fare better before the actor in the patent system that sees them the most - the USPTO. But even at the USPTO, there are not a large number of regulations being adopted that specifically benefit the individual inventor. Thus, those who engage the patent system for reform should take this Article's findings to heart, to better understand in which institutions the motif has more power and greater potential to prompt true change. This study also provides a broader picture as to how the various institutions are operating in the patent system to the benefit or detriment of small, independent inventors, additional information that reformists can use going forward. 